\title{
High vs Low Academic Achievement: What Difference Does Sleep Make? [Response to Letter]
}

This article was published in the following Dove Press journal:

Advances in Medical Education and Practice

\author{
Rostam Jalali (iD) \\ Habibolah Khazaie ${ }^{2}$ \\ Behnam Khaledi Paveh' \\ Zinab Hayrani (D) \\ Lida Menati' \\ 'Faculty of Nursing and Midwifery, \\ Kermanshah University of Medical \\ Sciences, Kermanshah, Iran; ${ }^{2}$ Sleep \\ Disorders Research Center, Kermanshah \\ University of Medical Sciences, \\ Kermanshah, Iran
}

\section{Dear editor}

I read the letter to the editor about our article. ${ }^{1}$ I am glad to hear from Miss Sodeinde about this topic. There are many studies on the association between sleep quality and academic performance, but as you know, despite the meta-analysis and systematic review ${ }^{2}$ in this regard, a uniform sound is not heard and some studies have shown that there is no relationship.,

As a researcher interested in this subject, I was looking for an answer to this ambiguity. According to qualitative researchers, qualitative sampling can be used in quantitative research and vice versa to find better answers to their questions. One method is to use purposeful sampling. To draw a purposive sample, a researcher begins with specific perspectives in mind that he or she wishes to examine and then seeks out research participants who cover that full range of perspectives. Purposeful sampling is oriented towards the development of idiographic knowledge - from generalizations from and about individual cases. ${ }^{5}$

Therefore, purposive sampling was used. We do not deny the confounding variables in the descriptive study and we believe that our expectations from the results of descriptive research should be the same as descriptive research. In this article, ${ }^{1}$ we have also recommended conducting a longitudinal study and a greater sample size.

Regarding the grade point average (GPA), we used the highest and lowest grade points in each field, and the GPA of these students in each field could be similar or different. However, this study tried to find an answer to the relationship between sleep quality and academic performance by qualitative sampling. We hope that we have been successful in this direction.

\section{Disclosure}

The authors declare no conflicts of interest in this communication.

\section{References}

1. Jalali R, Khazaie H, Paveh BK, Hayrani Z, Menati L. The effect of sleep quality on students' academic achievement. Adv Med Educ Pract. 2020;11:497-502.

2. Seoane HA, Moschetto L, Orliacq F, et al. Sleep disruption in medicine students and its relationship with impaired academic performance: a systematic review and meta-analysis. Sleep Med Rev. 2020;53:101333. doi:10.1016/j.smrv.2020.101333

3. Al-Khani AM, Sarhandi MI, Zaghloul MS, Ewid M, Saquib N. A cross-sectional survey on sleep quality, mental health, and academic performance among medical students in Saudi Arabia. BMC Res Notes. 2019;12(1):665. doi:10.1186/s13104-019-4713-2 
4. Sweileh WM, Ali IA, Sawalha AF, Abu-Taha AS, Sa'ed HZ, Al-Jabi SW. Sleep habits and sleep problems among Palestinian students. Child Adolesc Psychiatry Ment Health. 2011;5(1):25. doi:10.1186/ 1753-2000-5-25
5. Sandelowski M. Combining qualitative and quantitative sampling, data collection, and analysis techniques in mixed-method studies. Res Nurs Health. 2000;23(3):246-255.

Dove Medical Press encourages responsible, free and frank academic debate. The content of the Advances in Medical Education and Practice 'letters to the editor' section does not necessarily represent the views of Dove Medical Press, its officers, agents, employees, related entities or the Advances in Medical Education and Practice editors. While all reasonable steps have been taken to confirm the content of each letter, Dove Medical Press accepts no liability in respect of the content of any letter, nor is it responsible for the content and accuracy of any letter to the editor.

\section{Publish your work in this journal}

Advances in Medical Education and Practice is an international, peerreviewed, open access journal that aims to present and publish research on Medical Education covering medical, dental, nursing and allied health care professional education. The journal covers undergraduate education, postgraduate training and continuing medical education including emerging trends and innovative models linking education, research, and health care services. The manuscript management system is completely online and includes a very quick and fair peer-review system. Visit http://www.dovepress.com/testimonials.php to read real quotes from published authors. 